\title{
PREVALENCE AND AETIOLOGICAL FACTORS OF URINARY TRACT INFECTION IN FEBRILE CHILDREN 2 MONTHS TO 2 YEARS
}

\author{
Mohammed MTP1, Adarsh $U^{2}$
}

1 Professor and HOD, Department of Paediatrics, Academy of Medical Sciences and Medical College, Pariyaram, Kannur. 2 Post Graduate Trainee, Department of Paediatrics, Academy of Medical Sciences and Medical College, Pariyaram, Kannur.

ABSTRACT

\section{OBJECTIVES}

To determine the prevalence of urinary tract infection and etiological factors in recurrent urinary tract infections in febrile children, 2 months to 2 years of age.

\section{METHODS}

It was a hospital-based cross-sectional study conducted in the OPD of a tertiary care teaching hospital; 239 children between the ages of 2 months to 2 years with fever of more than 5 days were evaluated for UTI. Those who have $>5$ pus cells in urine analysis, urine culture was done. Children with recurrent UTI were evaluated by abdominal ultrasonogram, MCU and DMSA scan.

\section{RESULTS}

Total number of children studied were 239, prevalence of urinary tract infection was $11.3 \%, 2-6$ months of age (18.75\%) and 7-12 months of age (14.14\%). E. coli constituted $62.96 \%$. Among children with recurrent urinary tract infection, pyelonephritic changes in DMSA scan were present in 4 (36.3\%) and VUR was present in $2(16 \%)$ in MCU.

\section{CONCLUSIONS}

Urinary tract infection is a significant problem to be looked for in febrile children 2 months to 2 years. In recurrent UTI, any underlying problems like VUR should be considered and evaluated.

\section{KEYWORDS}

Febrile Children, UTI, Recurrent UTI.

HOW TO CITE THIS ARTICLE: Mohammed MTP, Adarsh U. Prevalence and aetiological factors of urinary tract infection in febrile children 2 months to 2 years. J. Evolution Med. Dent. Sci. 2016;5(22):1140-1142, DOI: 10.14260/jemds/2016/265

\section{INTRODUCTION}

Urinary Tract Infection (UTI) is one of the most common serious bacterial infection in febrile infants and young children and more common than bacterial meningitis, pneumonia and occult bacteraemia. ${ }^{1}$ It includes $10 \%$ of all febrile children, $13.6 \%$ of febrile infants and $7 \%$ of febrile newborns. ${ }^{2}$ About $8 \%$ of girls (3\% pre-pubertal) and $2 \%$ of boys (1\% pre-pubertal) experience at least one episode of UTI up to the age of 7 years. ${ }^{3}$ Unlike occult bacteraemia or severe bacterial illness (In infants and children) little attention has been focused on the identification of urinary tract infections in febrile children in the emergency department, despite recent information that suggests a high prevalence of urinary tract infections and significant associated morbidity in these patients.

UTI may lead to transient renal failure in $40 \%$ and permanent renal damage in $5 \%$ of patients. ${ }^{3}$ Quite often child receives antibiotics empirically without adequate evaluation for urinary tract infection. Fever, however, may be the only symptom in children with urinary tract infections. Fever and significant bacteriuria and pyuria in children without other foci of infections must be presumed to be pyelonephritis and prompt treatment should be commenced.

Financial or Other, Competing Interest: None.

Submission 22-01-2016, Peer Review 16-02-2016,

Acceptance 23-02-2016, Published 15-03-2016.

Corresponding Author:

Dr. Mohammed MTP,

Professor and HOD, Department of Paediatrics,

Academy of Medical Sciences and Pariyaram Medical College,

Kannur, Kerala.

E-mail:drmtpmohd@yahoo.com

DOI: $10.14260 /$ jemds/2016/265
Acute pyelonephritis consists of $2 / 3$ of febrile UTIs in early childhood. ${ }^{1}$ Recent studies using renal parenchyma-avid nuclear scans have revealed that more than $75 \%$ of children under 5 years of age with febrile urinary tract infection have pyelonephritis. ${ }^{4,5,6}$ Pyelonephritis leads to renal scarring in $27 \%$ to $64 \%$ of children with urinary tract infections in this age group, even in the absence of underlying urinary tract abnormalities. 7,8 Most urinary tract infections that lead to scarring or diminished kidney growth occur in children younger than 4 years of age, especially in the first year of life.5,8 It is essential to identify urinary tract infection in febrile children early and institute prompt treatment to reduce the potential for lifelong morbidity.

Optimum treatment results in symptomatic relief, prevents progressive renal damage and urosepsis with immediate bacterial eradication. ${ }^{9}$ Progressive renal damage from unrecognized pyelonephritis in childhood may lead to hypertension and chronic renal failure in later life. A study from Sweden showed that focal renal scarring caused by pyelonephritis in children carried a $23 \%$ risk for hypertension, a $10 \%$ risk for end-stage renal disease and a $15 \%$ risk for toxemia during pregnancy as an adult.10 Approximately, $13 \%$ to $15 \%$ of end-stage renal disease is thought to be related to urinary tract infection in childhood that was often unrecognized and therefore undertreated. ${ }^{11}$ The present study is undertaken to estimate the prevalence and etiological factors of urinary tract infection among febrile children 2 months to 2 years of age.

\section{METHODS OF STUDY}

This is a hospital-based cross-sectional, observational study. The study was conducted among 239 children with fever for more than 5 days without localizing signs, between the ages of 2 months to 2 years attending the Paediatric OPD of 
Pariyaram Medical College Hospital during one year (From April 1, 2013 to March 31, 2014). The sample size was calculated using the formula $4 p(1-p) / d 2$ where " $p$ " is the prevalence and " $\mathrm{d}$ " is the absolute precision. By taking the expected prevalence of UTI as $12.3 \%$ and absolute precision of $4.5 \%$, sample size was estimated to be 213 . A detailed proforma for collecting data related to age, sex, nutritional status, socioeconomic status (Using Kuppuswamy Socioeconomic status scale) and predisposing risk factors like urethral instrumentation, bowel habits, etc. was prepared. Complete history related to the onset of fever, duration associated symptoms such as nausea, vomiting, diarrhea, urinary disturbances and other system involvement was obtained.

Thorough physical examination was done in all patients. Routine blood counts, urine analysis were done for all patients and those showing pus cells $>5$ per HPF in centrifuged urine sample were taken as study group and urine culture sensitivity were done. If recurrent UTI $(\geq 2$ episodes), a thorough physical examination and USG abdomen/renal function test/DMSA/MCU was done for that patient to find out the abnormalities that predispose to recurrent infections. The details of the history, physical examination as well as laboratory findings were entered in the proforma.

\section{STATISTICAL ANALYSIS}

The data were entered into Microsoft Excel 2007 and were analysed using Epi Info 7 software. The results were described using frequencies and proportions. Inferential statistics like Chi square test and Fisher exact test were used in appropriate situations to test the significance of association between various etiological factors and occurrence of UTI.

\section{RESULTS}

Total number of children studied were 239, among them 147 children were below 1 year and 92 above 1 year, 108 were males and 131 were females; 56 children showed significant pyuria (23.4\%) and among them 27 children (48.2\%) showed culture positivity. The overall prevalence rate of urinary tract infection in the present study was $11.3 \%$ with maximum prevalence between 2-6 months of age (18.75\%) and 7-12 months of age (14.14\%). Among culture positive cases, majority (62.96) grew E. coli followed by Klebsiella (14.81\%), Proteus species $(11.11 \%)$ ), coagulase negative staphylococci $(3.70 \%)$ and mixed growth in $7.41 \%$. Urine culture was positive in $27.5 \%$ and $100 \%$ of children with pus cells 5 10/HPF and $>10 /$ HPF respectively.

Proportion of UTI is more in uncircumcised male (13.6\%) compared to circumcised male (10\%). Good bowel hygiene was present in $10.2 \%$ and in $18.2 \%$ it was poor. Among 239 children, 206 children were having good bladder hygiene, 33 were having poor bladder hygiene. Proportion of urinary tract infection were $10.2 \%$ and $18.2 \%$ respectively in good v/s poor bladder hygiene, i.e. higher in those with poor hygiene.

Among 239 children, pinworm infestation was present in 56 and absent in 186. Among children with pinworm infestation $12.5 \%$ were having UTI and among children without pinworm infestation $10.9 \%$ were having UTI. Proportion of UTI among children with constipation was
$15.8 \%$, which is higher compared to those who have regular bowel habits (10.9\%).

Among children with recurrent urinary tract infection, features of pyelonephritis in DMSA scan (Enlarged kidneys and photopenic areas) were present in $4(36.3 \%)$ children and grade 3 VUR (Reflux into dilated ureter) was present in 2 children (16\%) in MCU and no reflux in rest 10 children (84\%).

\begin{tabular}{|c|c|c|c|}
\hline \multirow{4}{*}{$\begin{array}{l}\text { Age Groups } \\
\text { (In Months) }\end{array}$} & $2-6$ months & 48 & $20 . \%$ \\
\hline & $\begin{array}{l}\text { 7th-12 } \\
\text { months }\end{array}$ & 99 & 41.42 \\
\hline & $\begin{array}{l}\text { 13th-18 } \\
\text { months }\end{array}$ & 26 & 10.88 \\
\hline & $\begin{array}{l}\text { 19th-24 } \\
\text { months }\end{array}$ & 66 & 27.62 \\
\hline \multirow{2}{*}{ Sex } & Males & 108 & 45.19 \\
\hline & Females & 131 & 54.81 \\
\hline \multirow{4}{*}{$\begin{array}{l}\text { Socio- } \\
\text { economic } \\
\text { Status }\end{array}$} & Upper & 2 & 0.84 \\
\hline & $\begin{array}{l}\text { Upper } \\
\text { middle }\end{array}$ & 93 & 38.91 \\
\hline & $\begin{array}{l}\text { Lower } \\
\text { middle }\end{array}$ & 125 & 52.30 \\
\hline & $\begin{array}{l}\text { Upper } \\
\text { lower }\end{array}$ & 19 & 7.95 \\
\hline \multirow{2}{*}{$\begin{array}{c}\text { Previous } \\
\text { History of UTI }\end{array}$} & $\begin{array}{l}\text { No } \\
\text { previous } \\
\text { history }\end{array}$ & 222 & 92.89 \\
\hline & $\begin{array}{l}\text { Previous } \\
\text { history of } \\
\text { UTI }\end{array}$ & 17 & 7.11 \\
\hline \multirow[b]{2}{*}{$\begin{array}{l}\text { Congenital } \\
\text { Anomalies }\end{array}$} & Absent & 235 & 98.33 \\
\hline & Present & $\begin{array}{c}4 \\
\text { (Absent left } \\
\text { kidney - } 1 \\
\text { Pre-auricular } \\
\text { sinus } \\
\text { and tag - 3) } \\
\end{array}$ & 1.67 \\
\hline & Total & 239 & 100 \\
\hline \multicolumn{4}{|c|}{$\begin{array}{c}\text { Table 1: Distribution of study participants across } \\
\text { different age group, sex, socio-demographic and } \\
\text { clinical variable }\end{array}$} \\
\hline
\end{tabular}

\section{DISCUSSION}

Urinary tract infections are common, potentially serious infections of childhood. They can cause acute morbidity as well as long-term sequelae including hypertension and impaired renal function. Accurate diagnosis of urinary tract infection is important to facilitate appropriate management and to ensure appropriate evaluation and follow up. Prevalence of UTI in febrile infants in our study, 2-6 months9 (18.75\%), 7-12 months-14 (14.14\%), which is slightly higher in contrast to study conducted by R.K. Kaushal et al.12 (2003) who reported higher prevalence of $8.4 \%$ and $12.3 \%$ in children $<5$ years and infants respectively. Prevalence of febrile UTI in infants in our study is higher compared to study by Dharni Dharaka et al.13 (1993) who reported a prevalence of $5.4 \%$ in febrile infants and Hoberman et al.14 (1993) who reported prevalence of $5.3 \%$ in infants. Overall prevalence of febrile UTI in children $(11.3 \%)$ in our study was higher compared to report by Shaw KN et al. ${ }^{4}$ (1998) from USA, who reported prevalence of $3.3 \%$ in febrile infants. This difference may be due to exclusion of children who was having other focus of infection. 
Because of financial constraints urine cultures were done only in children who showed significant pyuria, which revealed positive culture in $48.2 \% ; 100 \%$ of children who showed $>10$ pus cells were culture positive and $27.50 \%$ who showed $>5$ but $<10$ pus cells.

Hence, the presence of pyuria of $>5$ leukocytes/HPF in a centrifuged sample is a significant indicator of UTI. More number of cases were seen in uncircumcised males $(13.6 \%)$ compared to circumcised males (10\%), but the association was not statistically significant. Proportion of UTI in those with good bowel hygiene (No constipation, no faecal soiling, cleaning the perineum with water and wiping from front to back) was $10.2 \%$, which is less compared to those with poor bowel hygiene (18.2\%).

Proportion of urinary tract infection is higher in those with poor bladder hygiene-18.2\%. But both these associations were not statistically significant. Among children with pinworm infestation, $12.5 \%$ were having UTI compared to children without pinworm infestation $10.9 \%$; 11 children had recurrent urinary tract infection and among them 2 children $(18 \%)$ showed vesicoureteric reflux. According to Chand et al. ${ }^{15}$ primary VUR occurs in less than $1 \%$ of the general population and as many as $50 \%$ of children who present with recurrent UTI will have VUR. More than $75 \%$ of children under 5 years of age with febrile UTI have pyelonephritis stated by recent studies using renal parenchyma, avid nuclear scans to determine the presence of UTI. ${ }^{6}$ Higher risk for renal scarring is seen in children under 3 years of age with recurrent UTI. ${ }^{16}$

\section{CONCLUSION}

UTI should be considered as one among the differential diagnosis of fever without localizing signs in infants and children. It is not enough to treat the child with UTI, but to look for any underlying cause like VUR or obstructive uropathy is equally important. As an initial screening test urinalysis is useful and pus cells count of $>5 / \mathrm{HPF}$ is suggestive of UTI and a count of $>10 / \mathrm{HPF}$ is highly suggestive of UTI and a culture of the urine is required to confirm the diagnosis. In culture positive UTI, it is always important to do an MCU/DMSA scan to look for VUR and pyelonephritic changes/renal scars, respectively. Prevalence of UTI is more common in 2-6 months and least common in 13-18 months. Prevalence of culture positivity was $100 \%$ in those who showed $>10$ pus cells/HPF in centrifuged sample of urine.

\section{REFERENCES}

1. Keren R. Imaging and treatment strategies for children after first urinary tract infection. Curr Opin Pediatr 2007;19(6):705-10.
2. Bauer R, Kogan BA. New developments in the diagnosis and management of paediatric UTIs. Urol Clin North Am 2008;35(1):47-58.

3. Williams GJ, Lee A, Craig JC. Long-term antibiotics for preventing recurrent urinary tract infection in children. Cochrane Database Systematic Reviews [internet] 2001;(4):CD001534.

4. Shaw KN, Gorelick MH. Urinary tract infection in the paediatric patient. Paediatric clinics of North America 1999;46(6):1111-23.

5. Benador D, Benador N, Siosman DO, et al. Cortical scintigraphy in the evaluation of renal parenchymal changes in children with pyelonephritis. J pediatr 1994;124:17-20.

6. Majd M, Rushton HG, Jantausch B, et al. Relationship among vesicoureteral reflux, P-fimbriated escherichia coli and, acute pyelonephritis in children with febrile urinary tract infection. J Pediatr 1991;119:578-585.

7. Rushton HG, Majd M, Jantausch B, et al. Renal scarring following reflux and non reflux pyelonephritis in children: evaluation with $99 \mathrm{~m}$ technetiumdimercaptosuccinic acid scintigraphy. J Urol 1992;147(5):1327-1332.

8. Berg UB. Long term follow-up of renal morphology and function in children with recurrent pyelonephritis. J Urol 1992;148(5 Pt 2):1715-1720.

9. Malhotra SM, Kennedy WA. Urinary tract infections in children: treatment. Urol Clin North Am 2004;31(3):527-34, x.

10. Jakobson SH, Eklof O, Eriksson CG, et al. Development of hypertension and uraemia after pyelonephritis in childhood: 27 year follow up. BMJ 1989;299:703.706. doi:10.1136/bmj.299.6701.703.

11. Conway JJ, Cohn RA. Evolving role of nuclear medicine for the diagnosis and management of urinary tract infection [editorial]. J Pediatr 1994;124(1):87-90.

12. Kaushal RK, Bansal S, Sharma VK, et al. Urinary tract infection among children presenting with fever. Indian Pediatr 2003;40:269-270.

13. Dharni Dharka VR. Prevalence of bacteriuria in febrile infants. Indian Pediatrics 1993;30:981-986.

14. Hoberman A, Chao HP, Keller DM, et al. Prevalence of urinarytract infection in febrile infants. J pediatr 1993;123(1):17-23.

15. Chand DH, Rhoades T, Poe SA, et al. Incidence and severity of vesicoureteral reflux in children related to age, gender, race and diagnosis. J Urol 2003;170(4 t2):1548-50.

16. Cohen M. Urinary tract infections in children: females aged 2 years through first two infections. Pediatrics 1972;50:271-8. 